\title{
Justification of the Citizens' Right of Access to Public Passenger Transport Services by the Human Rights to Mobility and Equality Before the Law
}

\author{
BRANKO KORŽE \& IVANA TUCAK
}

\begin{abstract}
As opposed to authors who strive to justify the right of access to public passenger transport services of citizens predominantly on the principles of justice deriving from social ethics, the authors of this article justify the right of such access on the human rights to mobility and equality before the law, as the rights based on international legal acts, whereas the principles of fairness are used to upgrade the human right to equality and prohibition of discrimination. Based on the rights to mobility and equality before the law, the authors justify an obligation of democratic states to introduce a law to provide for people an adequate access to public passenger transport services at the interurban and urban level. The theoretical findings established herein will serve as a basis to evaluate legal regulations in the selected states (the Republic of Slovenia and the Republic of Croatia), and create proposals to change the same.
\end{abstract}

Keywords: $\bullet$ human rights $\bullet$ mobility $\bullet$ equality before the law $\bullet$ public passenger transport $\bullet$ accessibility

CORRESPONDENCE ADDRESS: Branko Korže, Ph.D., Professor, University of Ljubljana, School of Economics and Business, Kardeljeva plošad 17, 1000 Ljubljana, Slovenia, email: branko.korze@ef.uni-lj.si. Ivana Tucak, Ph.D., Associate Professor, Josip Juraj Strossmayer University of Osijek, Faculty of Law, Radićeva 13, 31000 Osijek,Croatia, email: itucak@pravos.hr.

https://doi.org/10.4335/19.1.149-174(2021)

ISSN 1581-5374 Print/1855-363X Online C 2021 Lex localis

Available online at http://journal.lex-localis.press. 
Introduction presents the scientific problem of the article, its novelty, exploration of the problem, aim, objective, research methods). The issue of user access to public passenger transport services (hereinafter PPT services) has been studied in the scientific literature with regard to various criteria, including geographical, infrastructure, economic, location-based, utility-based, town-planning criteria (Geurs, Van Wee, Rietveld, 2006), etc. Numerous scientific discussions have also been held in the field of studying the meaning of user access to PPT services from the aspect of social and ecological externalities that are reflected in the reduced use of passenger cars, reduced emissions and noise, less congestions in traffic (Geurs, Ponce Dentinho, Patuelli, 2016). Their starting point is predominantly theories of justice (e.g. Van Wee, Geurs, 2011), such that some of them justify the right of citizens to access PPT services also on the theory of justice in relation with equality without explaining its legal meaning (e.g. Pereira, Schwanen \& Banister, 2016). With the intention to justify the right of access to PPT services, Martens, along with analysing other theorists, focuses in particular on Rawls' theory of (distributive) justice, and finds that that serves well as far as the distribution of primary goods is concerned. However, it is short of justifying the right of user access to PPT services, because its social dimension (to consider users' personal circumstances, such as age, gender, etc.) is lacking. In relation to Dworkin's theory of fair principles, Martens (2017: 68) emphasizes that Dworkin connects his theory of fairness with the concept of insurance schemes for the users of PPT services, and opines that it is acceptable to differentiate among citizens in the distribution of access to PPT services only if it is to the benefit of those in a worse economic situation. This shortcoming is in his opinion to be remedied by the so-called "prioritarianism", by introducing mitigating measures to ensure access in relation to the actual situation of an individual person (Martens, 2017: 149). We believe that the theories of justice, in particular of those authors that connect them with the principle of equality, are more than necessary to justify the access of citizens to PPT services, especially to the benefit of those users who are subject to specific life circumstances (e.g. socially weak and/or those living in remote hill and mountain areas); as inhabitants who are otherwise not covered by the general standard of access applying to urban areas, and need to be ensured such access by special measures. Beyazit (2017) stems from justice as a basis to create equality before the law and discusses justice criteria in procedures to decide on investments in transport activities, which should contribute to improving the equality before the law and mobility. Hananel and Berechman (2016) ground the right of access to JPP services on the theory of social justice, by which fair distribution of goods is to be ensured, and establish that in the decisions thereof market criteria prevailed in the last decades under the influence of neoliberalism, which are contrary to social justice. In connection with the access to JPP services, Pereira, Schwanen and Banster (2017) state various theories of justice and, in 
relation to justice and equality, establish that there is no clear difference between these two concepts in the academic literature. Due to a deficient conception of the human right to equality or equality before the law and positive discrimination, they themselves do not surpass the unclear conceptions established (Pereira, Schwanen and Banster, 2017).

The topic addressed in this article is distinct from the aforementioned studies as it justifies the right of citizen (user) access to PPT services on legal bases, that is on the human rights (hereinafter HR or HRs) to mobility and equality before the law or positive discrimination. The authors depart from the aspect of the obligation of states, signers of international legal documents, to protect, respect, and remedy HRs violations. In this meaning, the states have to provide conditions for their citizens to be able to exercise their HR to mobility as part of their freedom and HR to equality before the law. PPT services are one of the relevant mechanisms to exercise the HR to mobility, some other HRs, and broad interests (objectives) of society. Based on the identification of HRs as a dynamic phenomenon whose substance is predominantly determined by the conditions of every social (state) entity, the authors justify the duty (obligation) of each individual democratic state to organize the PPT services in a manner that will be in compliance with the actual situation and the possibilities (ability) of the society (state). On that principle, the authors justify in a legal manner the right of different states to regulate standards of access (funding) at a different level. The legal right of a majority of citizens to access PPT services is in the authors' opinion in accordance with the HR to equality before the law, whereas the right of users not being members of the majority is based on positive discrimination and fair principles as an essence of a law-governed state. Theories of justice are thus an immediate tool for systemic justification of positive discrimination measures, which in the authors' opinion are not enough to legally justify and regulate the right to access PTT services, and, as already mentioned, are not the focus of this discussion. In the article, the authors limit themselves to bus public transport, which is the most appropriate to justify their positions, however, their findings could also be used to evaluate other forms of public passenger transport.

The right of users to access PPT services justified by the HRs is the basis for testing if the access to PPT services in the selected countries is adequately regulated at the interurban and urban level. The findings obtained in the compliance test serve as the basis to formulate proposals that are to be submitted to the national legislatures.

Descriptive and abstraction methods are used in the theoretical part of the article, whereas the methods of analysis and comparison are used in the empirical part. 


\subsection{Systemic importance of human rights and freedoms in a democratic state}

In the anthropologic, moral, legal, political and broad social meanings, HRs and freedoms are one of the fundamental assumptions to understand modern economic, political and legal systems and processes. Human dignity is the basis which comprises the full scope of human existence, in all its manifestations, and is materialized through numerous HRs and freedoms (Lampe, 2010: 171). In principle, it is not allowed to limit these rights to a person as an individual, and to legal entities, being individuals joined in a collective body; the rights can only be limited to an extent that is strictly necessary for exercising the equal rights of other entities and for pursuing the public (social) interest. Following Smith, between individual and social interests there is no contradiction, but harmony (Senf, 2004: 44). In compliance with the ratified international HRs conventions, each democratic state is obliged to ensure the respect and protection of HRs as a value of civilization obtained (Korže, 2014: 6). It is not sufficient that the state and its bodies only refrain from direct involvement in exercising the HRs, it is its task to take all the necessary steps to enable exercising of HRs (Lampe, 2010: 171). The respect and protection of HRs to which people as natural persons and associations, in which people are joined, are entitled are the conditions for optimal and longterm stable economic and broader social development and the highest level of welfare in each democratic (state) community. It has to be emphasized that the exercise of HRs and freedoms should be in convergence with the exercise of the rights of others, such that mutual coexistence as well as successful social development are achieved.

\subsection{Legal sources from international documents on mobility and equality as human rights}

The General Assembly of the United Nations states in Article 1 of the Universal Declaration of Human Rights (hereinafter the Declaration) ${ }^{1}$ that all human beings are born free and equal in dignity and rights. On this basis, Article 7 of the Declaration provides that we are all equal before the law and entitled to the same legal protection. Article 2 stipulates that any discrimination is prohibited, and Article 13 of the Declaration determines that everyone has the right to freedom of movement, whereas in paragraph 2 of Article 21 it is defined that everyone has the right of equal access to public services in his or her country. The realization of the right to work from Article 23, the right to education written in Article 26 and the right of everyone to take part in cultural life and to enjoy the works of art from Article 27, directly depends on the exercise of the right to mobility. The General Assembly of the United Nations in 1966 adopted the International 
Covenant on Civil and Political Rights and the International Covenant on Economic, Social and Cultural Rights, by Resolution No. 2200 A (XXI). Among the political rights, the International Covenant on Civil and Political Rights explicitly regulates the right to move freely in Article 12, and Articles 2, 24, 26 and 27 provide that any discrimination concerning such is prohibited. In Article 25 that Covenant ensures every citizen the right and opportunity to access public services in the country in equal terms generally. On the basis of the Declaration, the International Covenant on Economic, Social and Cultural Rights, determines a catalogue of human economic, social and cultural rights. By ratifying the Covenants, the signatory states committed themselves to enact HRs in their national legal systems, including the right to freedom and the right to mobility as part of it with relatively independent significance. The latter is of essential significance itself and simultaneously for exercising numerous other HRs listed in the Declaration and the mentioned covenants, such as the right to work, the right to education, economic and cultural rights, and other social HRs that are important for the development of individuals and the community as a whole (Korže, 2015b). Based on the international legal documents, the Slovene Constitution in Article 14 determines that in Slovenia everyone shall be guaranteed equal HRs and fundamental freedoms, and that all are equal before the law; Article 14 of the Croatian Constitution has the same content. ${ }^{2}$ Paragraph 3 of Article 71 of the Slovene Constitution imposes on the legislature the duty of a special promotion of the economic, cultural and social advancement of the population living in mountain and hill areas.

In addition to the mentioned legal bases, the Republic of Slovenia and the Republic of Croatia as members of the EU are also bound to respect regulations adopted by the EU authorities in the areas that have been transferred to its exclusive competence when entering the Union.

In accordance with Article 106 of the Treaty on the Functioning of the European Union, ${ }^{3} \mathrm{EU}$ member states are empowered to define PPT services as activities of general economic interest, that is as products or services for which permanent, secure, and uninterrupted production is in the public interest ensured by the state or local communities to satisfy the needs, when and insofar as such cannot be ensured in the market to an appropriate extent and under equal conditions and at accessible prices. Theory states the intensity of a public interest as a basic criterion for decision of the state or local communities to organize and carry out PPT services (Mužina, 1999: 79). 


\subsection{Mobility as a human right and social phenomenon}

Mobility is an important component of human freedom. At the same time, it enables the maintenance and sustainability of numerous private and public interests. Therefore it has to be designed sustainably and should actually reduce traffic as well as meet the requirements of users for mobility in an individual state. The sustainable approach to the establishment of mobility requires solutions such that the use of resources will decrease along with the increase in mobility. Traffic is one of the main sources of air pollution and climate changes and thus mobility has to be environmentally acceptable, socially just, and at the same time should promote the development of economy. These objectives can be achieved by traffic policy measures such that the need for mobility is met, but the costs and collateral effects, risks and the use of natural resources are the lowest (Lampe, 2010: 300). Each democratic state has to establish mobility by mechanisms that will enable citizens to meet their requirements for free movement and be made possible to exercise all other HRs enabled by mobility, along with the protection of public interests.

\section{Public passenger transport as a relevant mechanism of mobility}

\subsection{Public passenger transport as a collective form of enabling mobility}

It has been established in Section 2 that exercising the right to mobility is a significant part of human freedom and that mobility significantly enables the exercise of numerous other HRs such as the rights to work, education, health care, cultural goods, etc. As the state is obliged to create the conditions for exercising and protecting HRs, and simultaneously to provide beneficial externals in the field of environment, a rational use of natural resources and the organization of collective forms of mobility such as PPT services are necessary. The focus of collective provision of PPT services and the focus of HRs on individual wellbeing bring to the fore a core concern of modern political morality, the relationship between social obligations and individual freedom (Augenstein, Lindahl, 2015). The competent state bodies have to consider the selection of means, the manner of meeting the requirements for mobility as well as the relevant facts. By means of an analysis of individual elements and all the elements together, the advantages and disadvantages of possible solutions have to be established so that the selected option can ensure efficient, cost-effective, and sustainable PPT services. Such an approach to the regulation of transport demands that the state organizes PPT services as public economic services, and that in doing so states are entitled to depart from the rules of competition, if so required by the public interest established on a legitimate basis (Repas, 2010). Therefore the state is obliged to define PPT services as a merit good (mixed public-private good) and to become 
actively involved not only in its organization but also performance, and exercise control over its implementation.

\subsection{Determination of the standards of access to PPT services on the human right to mobility}

Considering that most HRs are in their content conditioned by philosophic, economic, historical, moral, cultural and political traditions, the level of social development and the tradition of values of a certain community (Winston, 1989: 539-543) in time and place, a full exercise of the majority of HRs can be predominantly ensured at a national level and determined with characteristics of individual communities. According to the described principle, the values and standards are relative when defining the content of an individual HR (Winston, 1989: 540), which applies also to the standard of user access in individual democratic communities (social state). It means that every democratic state is obliged to supplement the protection of the HR to mobility such that PPT services are organizationally and functionally in line with its specific social circumstances. In the organization of PPT, the state is obliged to pursue various social externalities, and it is bound to organize access for individual categories of users on the principles of equality before the law and positive discrimination respectively, in a differentiating manner if needed. It has to adequately modify the "cost-benefit analysis" and follow the economic goals as long as it is not detriment to its social interests (Korže, 2015a).

When determining the content, volume, and structure of PPT services, and if it is possible to use public funds to co-finance them (so far as this is necessary in the public interest - Section 2.1), a democratic (welfare) state should, on one hand, start from the systemic concept and content of individual human, political, economic, and social rights and fundamental freedoms (Korže, 2012: 462) and, on the other hand, from its economic capabilities while taking into account the encouraging impact on economic growth and overall social development. The establishment of convergence between the two sides is a prerequisite to achieve the optimum social welfare in the field of PPT services.

\section{Justification of the access to PPT services on the human right to equality before the law}

\subsection{Theoretical Defining of the Right to Equality}

The right to equality is the 'right of an individual to equality ensured both in the legislative regulation and the application of law,' which 'together with the principle of a state governed by the rule of law and the principle of a social state 
B. Korže \& I. Tucak: Justification of the Citizens' Right of Access to Public Passenger Transport Services by the Human Rights to Mobility and Equality Before the Law

'signify the implementation of the principle of justice' (Šturm et al, 2002: 172). Equality as a social category refers to the 'equal value of a human being as an individual and member of human society as a totality', from which what follows is 'equal dignity that in principle requires from social organization equal (legal) treatment of individuals' (Flander, 2004: 48). Equality among people stems from the social evaluation of people as individuals, while legal equality is the equality among people in relation to legal norms, which are to be implemented on the basis of a political will (Mahnič, 2002: 357). By the concept of equality, we understand a matching between different objects, subjects, processes or circumstances in essential, however not all, characteristics. The comparison of the characteristics refers to quantity and quality; thus the principle of equality is crucially connected with the principle of justice as the essence of law (Korže, 2019). Theories that discuss the relation between equality and justice stem from different starting points and substantiate the existence of several types of justice. Schmid (2008) divides them into three basic groups: the theories of moral justice (e.g., the view of justice according to the Church's teaching, Aristotle, Kant, Smith, Marx), the theories of utilitarian justice (e.g., the view of Machiavelli, utilitarian theorists), and the anti-utilitarian theories of justice (Rawls' theory of fairness, egalitarian and non-egalitarian theories, communitarianism, and recognitions). Aristotel divides theory of justice into the commutative justice of exchange and distributive justice. While commutative justice requires arithmetic equality, distributive justice is understood as proportion, thus as a medium arithmetic value between equality and inequality (Schmid, 2008). Justice needs to be enabled as a rule by the state, which must determine what is equal, and on the basis of such a criterion to carry out the distributive function needs to be established (Schmid, 2008). Also Kant's theory stems from the concept of morality, however, his justice only exists in the justice of rules in conformity with special rules of particular cultures, thus we necessarily need a just legislature (Schmid, 2008: 69). In this sense, in Kant ethical and moral measures, the responsibility of societies and persons for justice are connected (Schmid, 2008). Following Smith, Bernd Senf (2004: 44) argues that between individual and social interests there is no contradiction, but harmony. According to utilitarian justice, what 'is considered just is what brings a benefit for the greatest number of people', 'justice is maximization of the sum (or the average value) of benefits'. The individual is pushed to the edge, what is just is inequality or treatment of individuals with disdain when such is necessary for the interest or a majority or to maximize the happiness of many. The goal of utilitarian justice is not equality (Schmid, 2008). Anti-utilitarian theories of justice are developed on the basis of criticising utilitarianism; what unites them is a thinking that the rights of individuals cannot be limited by the reasons of common benefits. It is still necessary to take care of the welfare of a fellow-being and the society to which they belong, since only moral norms cannot protect equal rights and freedoms of the individual to the fullest extent. They differ in the conception of equality, which egalitarian views take as a goal of justice, while non-egalitarian 
views it as a by-product, and not as a goal (Schmid, 2008: 77). Schmid (2008) opines that "equal" and "just" cannot be paradigmatically connected and that it is not possible to "follow equality because of its being just," not that "just treatment leads to greater equality." They hold that "just" has different levels of meaning and that a thorough analysis of theories of justice shows that a connection between "just" and "equal" cannot be postulated. Justice is an open-ending concept, thus it is not possible to clearly and generally determine what is "just". Derrida claims that justice cannot be thematised or objectivized, and that it is impossible to say this is just, even less I am just without betraying justice or even a right (Schmid, 2008). Ethics in the process of normative regulation is a social force that forms the background in which everyday debates on majority or political decisions are held about what is to be "just". "Justice" is generally not asserted through morality, which is here understood as a transcendental direction of individuals and groups, but on the basis of - always diverse sometimes even antagonistic interests. Kušej thus holds that perhaps it is not reasonable to ask how much is the requirement of equality and thereby equal positions "just", but should find the answer how to establish democracy as a form of government that always helps create majority interests considering thereby the interest of minority (Kušej, Pavčnik \& Perenič, 1989). "Justice" in society activities always depends on majority as if a majority accepts justice as a manner of its operation, then it will be respected, otherwise not. Therefore, what is a fundamental question is the relation between the law and social values, which values can be legally protected, how they influence one another, and what is to be the relation between them. The discussion on that should necessarily include the issue of a relation between morality and law, the issue of ideology of law (Kušej, Pavčnik \& Perenič, 1989: 97), as justice is the criterion of lawfulness (Igličar, 2000).

The authors of this article have established that full equality cannot be created while for equal protection of legal subjects it is necessary that their position is regulated in conformity with the criteria of justice. Peuer-Studer (2000: 27) has carried out the following axiom of justice: 'Persons need to be treated in view of standard $\mathrm{X}$ equally, if there are no reasons to treat them unequally, the reasons which cannot be reasonably refused'. In the mentioned sense, it is imposed on the legislature to regulate essentially equal states of facts equally, and essentially different ones in proportion to their difference unequally (Kranjc, 2002). According to Šadl (2002: 401), the basic question of the principle of equality is what should not be equated, while a legal issue refers to the question of when it is just to treat unequal equally. Concerning such, Šturm (2002:174) adds that it is equally unjust to treat unequal identically as treating equal differently. The principle of equality imposes on the legislature and those who implement legal norms that they should not differentiate between citizens arbitrarily, without a rational and actual reason. ${ }^{4}$ By distributive justice the equal protection and nondiscrimination of bearers of the HR to equality is ensured, which can be restricted 
as dictated by general (public) interests. As the authors stated, the right to equality needs to be separated from the right to equal protection, which in its practical exercise encompasses entitlements of legal subjects derived from the right to equality. From the right to equal protection follows prohibition against discrimination as a duty which requires from the addressees to refrain from treating legal subjects unequally based on unjustified reasons compared with others, since everyone is entitled to equal fundamental rights. Prohibition against discrimination "does not allow to the legislature to differentiate with regard to the ensuring, exercise, and protection of fundamental rights that would be based on personal characteristics of the individual or their social position" (Flander, 2004: 70).

In compliance with Radbruch, the general principle of equality obliges the legislature to regulate substantially equal cases in the same way and substantially non-equal cases in a different manner, considering their diversity and characteristics (Pavčnik, 1991: 29). The general principle of equality is therefore violated, when no valid reason arising from the nature of things and justifying legal distinction cannot be found, and therefore such a legal provision is arbitrary. The legislature is entitled to evaluate which actual statuses or life situations can be treated equally and which differently, but the principle of justice should not be violated and the acting arbitrary. The consequences of the adopted legal solutions (results) have to be studied in the assessment whether the principle of equality was violated. The principle of equality is violated, if the legislature's distinction is not really and reasonably justified and when a legitimate objective is not pursued by the distinction. The legislature has to have an established methodology framework of argumentation used for the distinction. Proportionality should exist between the purpose and the means applied by which it would like to achieve the objective [16]. In compliance with the principles stated, the European Court of Human Rights prepared a test of general application in case of Lithgow (Lampe, 2010: 455 ) with the aim to test discrimination; discrimination is concerned also in case when the state does not provide the required efficient means for the equal and/or non-discriminatory protection of the rights of individuals and associations of individuals. The admissibility of interference with equality is therefore tested by a usual test of arbitrariness. It is not necessary to demonstrate the necessity of interference due to the protection of rights of others (Decision of the Constitutional Court of the Republic of Slovenia No. 146/VIII 2). Non-equal treatment cannot be arbitrary and discrimination is admissible, if it is justified, objectively and appropriately for the achievement of a desired objective. 
B. Korže \& I. Tucak: Justification of the Citizens' Right of Access to Public Passenger Transport Services by the Human Rights to Mobility and Equality

Before the Law

\subsection{Theoretical Definition of the Concept of Positive Discrimination}

Positive measures do not mean a violation of the principle of equality and equal protection of legal subjects but are intended to exercise equal protection among them. An omission or refusal of necessary and appropriate adjustments, which are dictated by special circumstances, would thus interfere with the right to equal or non-discriminatory treatment (Šturm et al, 2011: 168). By such measures legal subjects as HRs bearers who due to objective reasons are in a worse position in relation to a majority, are positively discriminated against the majority, by which their position is improved and a higher level of equal protection is ensured in social relations (Pišek, 2010). Therefore, positive discrimination is a positive aspect of the principle of equality or equal protection (Mahnič, 2002:367). Flander (2004: 250) argues that what is understood by positive discrimination are situations in which a priority position of actually deprivileged social groups is established by institutional mechanisms, and the remedying of their existing (informal) inequality is thereby made possible. By such treatment of deprivileged groups, a social element is entered into the criteria of unjust equality and just equality, which supplements generally predominant political and economic criteria (Flander, 2004: 252). Between certain social groups and the measures of positive discrimination a reasonable proportion must be established (Flander, 2004: 252-3). Only when equal opportunities for different social groups are ensured, is an integral-value oriented development of society as a whole and consequently a higher level of its moral and legal development made possible (Flander, 2004: 248). The stabilization and integration oriented system dimension of effects of positive discrimination should not encroach on the protection of the basic principles of a democratic and rule-of-law state (Flander, 2004: 254). The legislature's evaluation of whether the conditions for positive discrimination of certain social groups or individuals should be carried out in conformity with justice, in the sense as discussed by the authors in the previous section.

\section{5 \\ Respect of the principle of equality and positive discrimination of users in the access to PPT services}

The HRs to mobility and equality before the law or positive discrimination are, in conjunction with the principles of a state governed by the rule of law and justice as the essence of law, a foundation of legally regulating the access of citizens of a democratic state to PPT services. The authors further stated (3.2.) that the content of HRs is determined in line with the economic, cultural, historical, political, and other social conditions of an individual social community, which means that regulation of the access can quantitatively and qualitatively vary from country to country. The states mainly establish the standards of access to PPT services to all categories of users (Gabrovec, Kotar, 2006) on the "cost-benefit analysis" that corresponds to the traditional theory of equality pursuing the supply 
of the majority of population (distributive justice) and excluding users who are not included in the majority as, e.g., displaced citizens in hill and mountain areas, citizens of the islands. The exclusion of these categories of users from the general access to PPT services is permissible due to the natural conditions and economic reasons and is not contrary to the HR to equality. The exclusion of the stated category of users from the access to the PPT services can become inadmissible and contrary to the HR to equality, if the state does not regulate the access by special individualized mechanisms. Specific life circumstances in which they live dictate that the state positively discriminates them by special forms of access to PPT services. The objective of positive discrimination is two-fold, on one hand, these users should get the opportunity of exercising equality in the access to PPT services when compared to the users living in urban areas and, on the other hand, the populated hill and mountain regions should remain in the public interest. The access for these users should be regulated in line with the principle of justice as the essence of law (on the basis of the theories of justice), which however is not a special focus of this article. For suitable practical solutions the legislature should justify extra solutions on the basis of positive discrimination and in line with existing experiences (Solomon, Titheridge, 2009), as an addition to the integrated transport of school children, and transport of workers and somewhere also other users, or according to the model of prior announcement of the needs of users (advanced booking) "door-to-door", which are organized by separately subsidized taxi services, or combine public transport with various types of commercial transport provided by either forestry personnel or other companies whose activities involve constant transport to individual mountain or hill areas (Korže, 2015 b). Only by such positive discrimination, in providing special approaches to the access to PPT services and additionally to financing them from public funds, can the state provide these users with the same starting position in the area of the access to administrative, healthcare, cultural, educational, recreational services, as well as to workplaces and purchasing, as provided to the other users in the state.

6
A test of compliance of the regulation of user access to PPT services at the urban and interurban level in the Republic of Slovenia and the Republic of Croatia, with the prescribed legal regulation

\subsection{Legal regulation in the Republic of Slovenia}

The Road Transport Act $2^{5}$ (hereinafter "Act") determines the conditions and method of performing PPT services in the domestic and international road transport and the bodies competent for the implementation and supervision over the implementation of the Act (Article 1). The purpose of the adoption of the new Act was to eliminate unnecessary provisions, reduce or lower the conditions of carrier operation to minimum allowed standards, and to ensure effective supervision and sanctioning of foreign carriers violating the Slovenian regulation. 
This Act transposes into the Slovenian legislation Directive of the European Parliament and Council Directive 2006/1/EC of 18 January 2006 on the use of vehicles hired without drivers for the carriage of goods by road ${ }^{6}$ and Directive 2003/59/EC of the European Parliament and of the Council of 15 July 2003 on the initial qualification and periodic training of drivers of certain road vehicles for the carriage of goods or passengers, amending Council Regulation (EEC) No. 3820/85 and Council Directive 91/439/EEC, and repealing Council Directive 76/914/EEC. ${ }^{7}$ Under Item 16 of paragraph 1 of Article 3, public transport is defined as $/$ transport, which is under the same conditions available to all users and is carried out for commercial purposes «. Public passenger road transport is defined as transport that is carried out on certain routes, according to a predetermined timetable, price and general conditions of carriage that is either on an interurban or city line (Item 17 of paragraph 1 of Article 3). The Ministry responsible for transport is in charge of professional-technical, organizational, developmental and certain administrative functions in the field of transport of passengers and goods in domestic and international road transport and the provision of public services (Article 4). PPT in domestic road transport is carried out as a public regular service, special regular service, permanent non-regular transport, service on call, an occasional service, taxicab transportation and as a special form of transport (Article 44).

A road PPT is, according to Article 45, traffic between bus stations and bus stops on a certain line, according to a pre-determined schedule, tariff and the general conditions of carriage that has to be adapted to people with disabilities. It can be performed only by bus and must be accessible to all passengers regardless of whether it may be subject to special reservation. Article 45 further prescribes that on certain lines and in certain periods due to a lower number of passengers regular PPT may be carried by transport vehicles, which in addition to the driver's seat have at least eight seats. The carrier has to operate under a registered timetable, price list, general conditions of carriage and the concession contract. The use of devices to overcome the physical and sensory disabilities (guide dogs, assistance dogs and other wheelchairs) should not be charged additional cost (Article 45). PPT services in domestic road transport can be carried out in the form of integrated public lines, special or other passenger transport (Article 48). Interruption and suspension of services concerning a line is prohibited under Article 49. As an exception, transport can be suspended or abandoned due to unforeseen or foreseen events if they occur and as long as the circumstances which cannot be predicted or avoided and whose consequences could not be averted continue to exist (Article 49).

According to Article 50, the PPT with the exception of PPT in urban (local) areas and the special regular service, is ensured by the state as a mandatory public economic service. The state (government), on the basis of a public tender, defines 
concession zones or tendering lines, standards of access, standards of quality, tariffs, way of financing, other concession elements, and awards concessions to the most favourable providers (Article 50). For the provision of PPT, the system of a single ticket has been introduced and all carriers providing PPT services are included in it (Article 50). This service of a general economic interest is financed from the price of the service, the budget of the Republic of Slovenia, and from other sources related to the performance of PPT services (Article 52). The aim of PPT services as public economic services is to redirect the users of transport from personal cars to public means of transport. Special attention is devoted to the categories of passengers migrating daily, namely pupils, students, workers and passengers from demographically endangered areas (Article 52).

Based on the study of the legal regulation of the PPT in Slovenia, the authors establish that in the area of interurban road transport in the Republic of Slovenia, mobility is at the normative level in conformity with the human right to mobility. The legislature regulated the access to PPT services as a public economic service selectively by separating the users, considering their essential characteristics, into different groups, such as pupils and students, slightly or severely physically impaired students, retired, service users beyond 65 years of age, users with a registered status of athlete (Article 114.b of the Act), and other categories of passengers daily migrating, such as workers, passengers from demographically endangered areas, as well as disabled and war veterans. In this way, it regulated the access to line PPT services such that it treated the users being in an equal actual position according to essential characteristics equally, whereas those who are on the basis of the same in different actual positions differently; thereby it ensured for the users equality before the law in the sense of the exercise of the human right to equality. The legislature authorized the Government of the RS to determine concession areas and lines of interurban PPT, standards of access and quality, tariff, and the way of financing (paragraph 2 of Article 50 of the Act). By the Regulation on the manner of implementing the public economic service of line public transport of passengers in internal road traffic, concession for this public service, and regulation of the system of a single ticket, ${ }^{8}$ the Government determined the manner of operation of the public economic service of line transport of passengers, the content and obligations of the public economic service, passenger rights, financing, the manner of granting concession and the supervision of its implementation. In Annex 1 to the Regulation, the Government determined concession areas and interurban lines, in Annex 2 the access standards, and in Annex 3 the tariff. The manner and methodology of calculation of a full price for the subsidized ticket from the state budget and the price paid by the beneficiary, and the categories of remoteness, were following the authorization given in paragraph 13 of Article 114.d of the Act, prescribed by the Minister competent for infrastructure in agreement with the Ministers competent for education and labour and social matters, in the Rules on determining the prices of 
subsidized transport. ${ }^{9}$ The Government and Ministry for infrastructure regulated the standard of user access to the interurban PPT services on the basis of the following criteria: number of departures of the public means of transport on a route in a certain timeframe, considering the size of the settlement, the settlement where the seat of the municipality is and the number of potential passengers in a periodic migration (Article 8 of Regulation). In accordance with the legal authorization, the Government prescribed that the performers of PPT services should minimally meet Euro 4 standard as the minimal standard of quality as well as the provisions specifying which standards the performers of transport services have to fulfil in the field of ensuring cleanliness (Articles 20 and 21 of Regulation). The legislature enabled the municipalities and other interested parties to upgrade (improve) the access standards on their proposal on certain routes under the condition that the funding for the increased standard of access to these services is provided. The proposer has to provide the sources of financing to cover the costs incurred by the higher standard (Articles 8 and 9 of the Regulation).

From the theoretical part of this discussion, it follows that the human right to mobility and equality before the law in the access of users to PPT substantially depends on the resources of a certain society (state) in time and place. This entails that the standards of access and subsidized prices is in the field of the legislature's discretion provided such that they do not act arbitrarily. The authors establish that the legislature ensures the human right to mobility and equality before the law in an appropriate manner by regulating the access of line PPT services in the Republic of Slovenia. In evaluating the standards of access, the authors did not find arbitrary measures. However, we point to the question of constitutionality of the regulation which we did not examine despite certain doubts of the regulation in this direction. The rights and obligations in a democratic state can only be regulated by the legislature by statute, and executive authorities can only be authorized to further implement the statutory provisions. In the legal regulation of access to PPT services the legislature predominantly left the forming of the rights to the executive authorities of government, which could be problematic.

With respect to the right to the access to PPT services of inhabitants living outside urban areas and those living in hill and mountain regions, which are in a special position in relation to the inhabitants of urban areas, the authors find that in Article 57.b of the Act the legislature provided the possibility of introducing transport on call and, further, that such transports are organized in the framework of the economic public service of line passenger transport in internal road traffic. It also determines that these forms of transport can be organized also in the frame of the local public economic service of passenger transport, if the basic criteria determined by statute for that are met and if the competent PPT authority issues to them a special permit. The authors establish that the Slovene legislature did not regulate the financing of the right to access for the mentioned categories of users 
in accordance with their human right to positive discrimination, nor in conformity with paragraph 2 of Article 71 of the RS Constitution. The statutory provisions on their right are only of a programmatic character and do not ensure a legal basis sufficient for their exercise. The legislature should remedy the lack of regulation such that it defines, in statute, the conditions and criteria as mandatory bases to bind the executive branch authorities when prescribing in more detail the special forms of accessibility for the mentioned categories of inhabitants.

The legislature of the RS left the regulation of the organization and method of carrying out the urban line PPT to municipalities. It is stipulated in Article 53 of the Act that the municipalities can specify the activity of urban line PPT as a public economic service (non-obligatory public economic service), whereas in urban areas having more than 100,000 inhabitants it is to be performed as a mandatory public economic service. The Act limits the performance of the urban line passenger transport to the area of an individual municipality, but if the needs for daily migrations of people to urban areas are justified these services are performed exceptionally; to a small extent they are performed also in the neighbouring settlements and if the municipality has obtained a license from the competent state authority. The legislature has imposed on municipalities the obligation to consider the volume of daily migrations and the size of gravitation area, interdependence of the urban and interurban line passenger transport, connections of the urban transport with other kinds of transport, and care for the rights of disabled persons when regulating the urban line passenger transport. The municipalities are competent to regulate the organization and performance of PPT, the standard of access to PPT services, offer, price policy, and a share of cofinancing services from the budget of municipalities, quality of the fleet (age of vehicles, share of emissions, share of low floor buses, etc.), and equipment of bus stops. The legislature specified the revenue from the sale of transport services to users and the funds from the budget of an individual municipality as the source of financing of carrying out urban line passenger transport (financing and/or confinancing of the transport).

The legislature gave local communities a legal basis to regulate local PPT, which resulted in inhabitants of different municipalities accessing to such services under completely different conditions. Following the data of the Ministry of Infrastructure, any municipality can organize PPT services under their "own" standards that reflect their organizational, financial and political reality. In accordance with such regulation, the standards of inhabitants' access to local PPT services are very different between the municipalities. Certain municipalities subsidize PPT entirely, to a full price, such as the Municipalities of Koper, Kranj, Nova Gorica, while some municipalities cover only part of the ticket price from the municipal budget. Individual municipalities, such as Koper, Dol, and Škofja 
Loka, subsidize transport also through additionally established interurban lines. What the municipalities also entirely differently regulate is also the access of their inhabitants to PPT service on call, as there is no common legal foundation for such (Ministry of Infrastructure, 2019). Thus, we find that the regulation of the user access to PPT services at the local level in the legal order of the Republic of Slovenia does not meet the conditions of protecting the HRs to mobility and equality before the law. To ensure the equality before the law of inhabitants with respect to local PPT services, the legislature should enact standards or at least basic criteria on the basis of which local communities would determine the standards in consistency with actual geographical, demographic, and social circumstances. In such a manner a minimal standard of the access to PPT services for the inhabitants of all municipalities in the Republic of Slovenia will be created, which is now completely different. Apart from the minimal standard of access, the legislature should enact a uniform manner of financing local PPT services, either by prescribing for all the local communities the same percentage of cofinancing from local budgets, or by enacting appropriate co-financing from the Republic of Slovenia budget to con-finance the tickets of inhabitants of those local communities who are in a worse economic situation.

\subsection{Legal regulation in the Republic of Croatia}

On 27 April 2018, the Croatian Parliament adopted the Road Transport Act (hereinafter "Act") ${ }^{10}$ in urgent procedure resulting from the burning issues which the road transport in Croatia had been facing as the most important segment of the transport system. Beside the need for regulation of the road transport of passengers and cargo prior to tourist season, the Government justified the urgent procedure with the need to resolve the issue of unprofitable lines and a lack of transport connections in rural and sparsely populated regions in Croatia (Government of the Republic of Croatia (a), 2018:4-5). By adopting the new Act, the Republic of Croatia embraced the acquis communautaire in the field of road passenger transport. For Croatia, of particular relevance in this light was Regulation (EC) No. 1370/2007 of the European Parliament and of the Council of 23 October 2007 on PPT services by rail and by road and repealing Council Regulations (EEC) Nos $1191 / 69$ and $1107 / 70^{11}$ amended by Regulation (EU) 2016/2338 of the European Parliament and of the Council of 14 December 2016 amending Regulation (EC) No 1370/2007 concerning the opening of the market for domestic passenger transport services by rail (hereinafter Regulation) ${ }^{12}$ (Government of the Republic of Croatia, 2018 (a): 4).

In the new Act, public transport is defined in the same way as in the equivalent Slovenian law, i.e. as a passenger transport available under the same conditions to all users, which carriers perform for commercial gain (Article 4, paragraph 1, item 18; cf. Article 3, paragraph 1, item 16 of the Slovenian Act). Road passenger 
B. Korže \& I. Tucak: Justification of the Citizens' Right of Access to Public Passenger Transport Services by the Human Rights to Mobility and Equality Before the Law

transport is arranged as a regular service, special regular service, shuttle service, occasional transport, transport by taxi, special forms of transport and a new form of transport called microtransport. The legislature determined the conditions that a transport undertaking has to meet, the conditions that a vehicle has to fulfil, and the supervision over the performance of the activity. Regular public road passenger transport (javni linijski prijevoz) is defined as passenger transport provided by a car with a tachograph (category M1), minibus (category M2) and bus (category M3), all in line with pre-defined lines, service timetables, prices and General Transport Terms and Conditions. Regular public road passenger transport is deemed as "a public economic service appearing as a public good, the performance of which is ensured by the Republic of Croatia in the public interest" (Article 4, paragraph 1, item 19). In terms of relevant provisions of PPT, a single ticket system has been introduced, just like in Slovenia, which allows passengers to use PPT services provided by different carriers (Article 4, paragraph 1, item 20; cf. Article 50 of the Slovenian Act).

Regular public road passenger transport can be provided as communal (komunalni), regional (županijski) or interregional (međužupanijski) passenger transport (Article 32, paragraph 2). Pursuant to the Public Utilities Act, communal passenger transport is considered a utility (Article 24, paragraph 1, item 4; Kemeter, 2018) ${ }^{13}$ comprising public passenger transport within zones defined by the local self-government concerned (Article 25, paragraph 4; Kemeter, 2018). The legal ground for its organization refers to a contract between an road transport operator and the local self-government concerned, which should be based on a decision of the representative authority of local self-government on communal transport, relevant laws and provisions of Regulation (EC) No 1370/2007 (Article 33, paragraph 1 of the Act; Kemeter, 2018).

The new Act has substantially changed the previous regulation of regional passenger line transport. The previous regulation was not satisfactory due to line unprofitability resulting from mass emigration and demographic issues in some parts of the country, particularly in Slavonia, Baranya and Syrmia. The crisis in that part of the country culminated in February 2018 when despite the fact that many lines were co-financed by the state itself, and local and regional selfgovernment, Arriva company terminated 72 bus lines (Aničić, 2018) which put in jeopardy the transfer of pupils, students and workers to their schools, faculties and workplaces. The emerged situation, as highlighted above, was regarded as one of the Government's reasons for requesting adoption of the Road Transport Act in urgent procedure from the Croatian Parliament. In accordance with the new Act, regional passenger transport is based on Regulation (EC) No 1370/2007 (Government of the Republic of Croatia (a), 2018:4). On the ground of an analysis of passenger transport demand and supply from other transportation branches, the competent administrative authority of regional self-government determines "a 
network of regional passenger transport lines within its area of competence for the purpose of conclusion of a public service contract" (Article 33, paragraph 5). Interregional line transport (međužupanijski linijski prijevoz) is depicted as "public road passenger transport between bus stations or bus stops in two or more counties" (Article 4, paragraph 1, item 28). It can be organized as express or direct passenger line transport based on a permit issued after the harmonization of service timetables by the Ministry of the Sea, Transport and Infrastructure (Article 4 paragraph 1 item 28; Article 33 paragraph 4). According to Article 38 paragraph 1 of the Act, providing transport services may be temporarily suspended in the event of force majeure.

One of the key novelties of this Act is definitely introduction of a new form of transport called microtransport (Article 4 paragraph 1 item 26; and article 50; Mudrić, 2018; Kemeter; 2018). This represents one of the major Government's ways of combating the geographical isolation of sparsely populated parts of Croatia. It is defined as public passenger transport by passenger car (class M1) or minibus (class M2) in regions suffering from a lack of organized public passenger transport and low demand for such (Article 4, paragraph 1, item 26), particularly in rural and sparsely populated areas (Article 50, paragraph 3). Organization of microtransport requires a prior decision of the representative authority of local self-government (Article 50, paragraph 2; Kemeter, 2018). The Act also permits organization of microtransport in areas with organized public passenger transport on days when such is not available, e.g. during school and national holidays (Article 50, paragraph 11). Microtransport is performed pursuant to an agreement concluded between a contracting authority and a contractor (operator) in accordance with the decision of the competent local self-government unit (Article 50, paragraph 4) on the need for such transportation and the manner of bearing appertaining costs (Article 50, paragraph 6). It may be arranged that a contract on providing microtransport services has the character of a public service contract (Article 50, paragraph 9).

As one of the solutions to the issue of the economic feasibility of public passenger transport lines, the legislature has come up with a new regulation of integrated transport, the target goal is feasible, efficient and high-quality PPT (Article 53; Kemeter, 2018). Integrated PPT "comprises interrelated PPT services within a specific geographical area with a unique information service, a single ticket, i.e., a tariff system and a single timetable" (Article 52, paragraph 8). Those services can be provided in the area of one local or regional self-government unit or "in the area of several local and/or regional self-government units in a specific pilotarea" (Article 54). An operator and a local or regional self-government unit appear as the parties to a contract on providing integrated PPT services. Conclusion of such a contract requires prior consent of the Ministry of the Sea, Transport and Infrastructure (Article 55, paragraph 1). The contract is made for the purpose of 
defining an area, i.e. integration pilot-area, transportation line network, obligation for providing the respective public service, quality standard, remuneration and obligation for delivering service providing data (Article 56). "The PPT service providing obligation" is a claim made by the competent authority in order to ensure performance of transport by the operator who would not provide transport on such a scale and without compensation if only their commercial interests were taken into consideration (Article 52, item 4). Otherwise, providing this service of general (economic) interest would be improbable (Article 52, item 4).

The Ordinance on Providing Regular Public Road Passenger Transport ${ }^{14}$ sets forth, among other things, the procedure for concluding contracts on providing transport as a public service (Article 1). Pursuant to Article 11, paragraph 1 of the Ordinance, for the purpose of compensation of costs incurred through providing public services of general economic interests in public passenger line transport, a regional self-government unit and the City of Zagreb enter into a public service contract in compliance with Regulation 1370/2007. Furthermore, local selfgovernment units enter into a public service contract to compensate the same costs too (Article 11, paragraph 2). An annex to a public service contract may be aimed at enlargement of the line network and an increase of the public service quality (Article 11, paragraph 5). Regional self-government units and the City of Zagreb or several regional self-government units, if a public service is provided on their territory, launch a call for tenders, which should in the end result in a contract award (Article 12, paragraph 1) based on Regulation 1370/2007 or relevant public procurement provisions (Article 12, paragraph 3). Paragraph 4 of Article 12 prescribes exceptional situations in which a public service contract can be concluded without a tendering procedure. This service of a general economic interest is financed through respective charges, from the budget of the Republic of Croatia and from the budget of local self-government units, regional selfgovernment units and the City of Zagreb (Article 16).

The transfer of schoolchildren, disabled persons, passengers seeking medical assistance and commuters is considered a special regular service (Part IV. B of the Act). The Act contains no special provisions on co-funding school and college transport costs, as it is the case in the Republic of Slovenia (Article 114 of the Slovenian Act). Nevertheless, the Government of the Republic of Croatia, through its Ministry of Science and Education, co-finance school transport costs in areas covered by public passenger line transport (Croatian Chamber of Economy, Osijek County Chamber, 2017:53). The Government is currently implementing a programme of co-funding high school pupils' transport costs and the investment in the programme is gradually increasing. Namely, in the school year 2018/2019, the investment was increased by $22 \%$ comparing to the previous year (Government of the Republic of Croatia (b), 2018). In line with the Government's decision on the criteria and manners of covering high school transport costs for 
the school year 2019/2020, made in August 2019, the Ministry of Science and Education will cover 75\% of inter-municipal (međumjesnog) public transport costs to regular high school pupils whose place of permanent and temporary residence is located more than $5 \mathrm{~km}$ from their school. ${ }^{15}$ The Ordinance on the Conditions and Manner of the Exercise of the Right to Financial Support for Partially Covering Transport Costs, Provided to Full-Time Students with Disabilities is also in force. ${ }^{16}$

Through its Ministry of Regional Development and EU Funds, the Government has co-financed transportation of residents of islands since 2001 (Ministry of Regional Development and EU Funds, n.d.). The Islands Act regulates the right to supported public road transport on islands (povlašteni javni otočni cestovni prijevoz) (Article 31). ${ }^{17}$ Public road transport fares for lines connecting the mainland with islands or connecting two or more islands and fares for lines connecting places on one island will be adapted to transportation costs in a way that the former shall not be more expensive than those for public road transport covering the same distance in an appertaining regional self-government unit (Article 31, paragraph 1). The following islanders are entitled to free public road transport on islands: children under eight, pupils and students, pensioners, persons over 65, disabled persons and persons accompanying them (Article 31, paragraph 2). Beside the residents of islands, the same right is enjoyed by those attending school or studying on islands and those living in residential and nursing care homes (Article 31, paragraph 3). Special transfer privileges are provided to residents of hill and mountain areas. According to the Act on Hill and Mountain Areas, natural persons residing in hill and mountain areas are, based on a special identity card, mountain card (Article 26, paragraph 1), ${ }^{18}$ entitled to privilege public transport fares within a respective county (Article 26, paragraph 2).

Disabled persons are facing particular problems in public transport. As one of the signatories of the Convention on the Rights of Persons with Disabilities (CRPD), Croatia is obliged to undertake appropriate measures for ensuring them an access to transport as well as to other services and public premises, both in urban and rural areas, and on equal grounds with the rest of the population (Article 9, paragraph 1 of the Convention; Government of the Republic of Croatia, 2017). ${ }^{19}$ In compliance with the General Commentary of the UN Committee on the Rights of Persons with Disabilities No. 2 (2014), the state is bound to provide additional funds for ensuring disabled persons an access to public and private transport (Government of the Republic of Croatia, 2017). The Croatian National Strategy for Equalization of Opportunities for Persons with Disabilities 2017 - 2020 puts the emphasis on mobility and accessibility in shaping an inclusive society (Government of the Republic of Croatia, 2017). In accordance with the Strategy, local self-government units shall participate in providing disabled persons with an access to public road transportation (Ombudsperson for Persons with Disabilities, 
2018: 21). They are obliged to prepare local strategies and programmes for ensuring equal opportunities to this category of people and to appoint coordinators for implementation of the Strategy (Ombudsperson for Persons with Disabilities, 2018: 21). Pursuant to the Public Utilities Act, communal (komunalni) transport is regarded as a utility, which means that it is for the most part managed by local and regional self-government (Government of the Republic of Croatia, 2017).

Based on the study of the legal regulation of the PPT in Croatia, the authors establish that the Republic of Croatia lawfully regulates PPT and provides users with an access to PPT services at a normative (declaratory) level by respecting the HR to equality. PPT services have to be accessible to all users under equal conditions and without discrimination (Article 34). By adopting the new Act, the Republic of Croatia has enacted a series of new legal solutions, among which the shift from the system of authorization (dozvola) for performing regional passenger line transport to a new form of performing transport as a public service based on a public service contract between an operator and a regional self-government unit should be highlighted (Government of the Republic of Croatia (a), 2018:3). Since this is a new Act, it is too early to discuss the efficiency of the new institutions. However, regarding some category of people, particularly disabled persons, it is clear that the current situation is far from being satisfactory.

In her 2018 annual report, the Croatian Ombudswoman for Persons with Disabilities warned about the issues related to the mobility and inability of disabled persons to get involved in everyday activities, resulting from a lack of or inadequate availability of public transport services adapted to their needs (Ombudsperson for Persons with Disabilities, 2018: 204). The lack of transport services is particularly evident in smaller places, rural areas and on islands (Ombudsperson for Persons with Disabilities, 2018, paragraph 21.2.1). The report sheds light on the fact that the disabled persons living in those areas often have no possibility to use transport services. Transportation problems particularly affect Slavonia, Baranya and Syrmia. Following numerous complaints received by her subsidiary in Osijek after its opening in November 2018, the Ombudswoman gave a recommendation to all Slavonian counties (Osijek-Baranya, Brod-Posavina, Virovitica-Podravina, Vukovar- Syrmia and Požega-Slavonia) to engage in improving the current condition (Ombudsperson for Persons with Disabilities, 2018: 30). She stressed the importance of ensuring mobility and transport for persons with disabilities and children with developmental disabilities by local and regional self-government as well as the importance of organizing free city and intercity transport by specially adapted vehicles (gradskog $i$ međugradskog prijevoza) (Ombudsperson for Persons with Disabilities, 2018: 21). Pursuant to the recommendations, all local and regional self-government units need to analyse the needs of persons with disabilities within their areas of competence, define priorities in cooperation with civil society organizations or individuals, draw up a 
local strategy and provide financial funds for its implementation (Ombudsperson for Persons with Disabilities, 2018: 30).

\section{$7 \quad$ Conclusions}

In line with the human rights to mobility and equality, the basic standard of PPT services and accessibility of users in urban areas to them has to be regulated on interregional, regional, and municipal (local) levels in every state uniquely (uniformly) - (local communities should actively participate in the systemic regulation of the PPT organization and accessibility of users to PPT services). The state has to positively discriminate the users being excluded from the majority (displaced in hilly and mountainous areas) by systemic measures, so that it organizes access to PPT services for them in accordance with the theories of justice, in particular of those authors that connect them with the principle of equality, so that access is adjusted to their actual living conditions.

The regulation of organization and financing of regional (interurban) and local PPT services in the Republic of Slovenia is in accordance with human rights to mobility and equality only on an interregional level, but not on the local levels (the legislative authorities are divided between the state and local levels, which causes different standards and accessibility to local PPT services between users living in different municipalities). In the Republic of Croatia there is inadequate access to PPT services in rural and sparsely populated regions, which is not in compliance with the human right to mobility. With respect to the right of disabled persons and children with developmental disabilities to public transport, the current situation is far from being satisfactory. The lack of transport services for this category of people is particularly evident in smaller places, rural areas and on islands. By adopting the new Act, the Republic of Croatia has enacted a series of new legal solutions, among which the shift from the system of authorization (dozvola) for performing regional passenger line transport to a new form of performing transport as a service of general economic interests should be highlighted. 
B. Korže \& I. Tucak: Justification of the Citizens' Right of Access to Public Passenger Transport Services by the Human Rights to Mobility and Equality Before the Law

\section{Notes:}

${ }^{1}$ Adopted and declared by the General Assembly of the United Nations on 10 December 1948 with Resolution No. 217 A (III).

${ }^{2}$ Consolidated text, Off. Gaz. RC, Nos 56/90, 135/97, 113/00, 28/01, 76/10 and 5/14.

${ }^{3}$ Consolidated version of the Treaty on the Functioning of the European Union, Official Journal of the EU, C 326/01, 26 October 2012.

${ }^{4}$ U-I-18/02 (2003), Item 12.

${ }^{5}$ Off. Gaz. RS, Nos. 6/16 - consol. text and 67/19.

${ }^{6}$ OJ L 33.

${ }^{7}$ OJ L 226.

${ }^{8}$ Off. Gaz. RS, No. 29/19.

${ }^{9}$ Off. Gaz. RS, Nos. 56/16 and 7/20.

${ }^{10}$ Off. Gaz. RC, No. 41/18. The Act was amended in 2019, Off. Gaz. RC, No. 98/19.

${ }^{11}$ OJ L 315.

12 OJ L 354.

${ }^{13}$ Off. Gaz. RC, No. 68/18, 110/18 and 32/20. See also Kemeter, 2018.

${ }^{14}$ Off. Gaz. RC, No. 116/19.

15 Odluka o kriterijima i načinu financiranja troškova javnog prijevoza redovitih učenika srednjih škola za školsku godinu 2019/2020, Off. Gaz. RC, No. 81/2019.

16 Off. Gaz. RC, No. 23/2015.

${ }^{17}$ Off. Gaz. RC, No. 116/18.

${ }^{18}$ Off. Gaz. RC, No.118/18.

${ }^{19}$ Off. Gaz. RC, No. 42/17.

\section{References:}

Aničić, L. (2018) Slavonci i Baranjci neočekivano pred novim problemom. Ukinute 72 autobusne linije - kako do škole, studija, posla?, Glas Slavonije, 7 February 2018, available at: http://www.glas-slavonije.hr/355319/4/Ukinute-72-autobusne-linije--kako-do-skole-studija-posla (August 5, 2019).

Augenstein, D. \& Lindahl, H. (2015) Global Human Rights Law and the Boundaries of Statehood, In: Kochenov, D., De Burca, G. \& Williams, A. (eds.) Europe's justice deficit. (Oxford: Hart), pp. 153-164.

Beyazit, E. (2011) Evaluating Social Justice in Transport: Lessons to be Learned from the Capability Approach, Transport Reviews: A Transnational Transdisciplinary Journal, 31(1), pp. $117-134$.

Croatian Chamber of Economy, Osijek County Chamber (2017, September) Stanje gospodarstva Osječko- baranjske županije. Izvješće za 2017. godinu, available at: https://www.hgk.hr/documents/stanje-gospodarstva-obzrujan-201759ef01f2cf62d.pdf (October 11, 2019).

Flander, B. (2004) Pozitivna diskriminacija (Ljubljana: Fakulteta za družbene vede).

Gabrovec, M., Kotar, M. (2006) Izdelava standardov dostopnosti do javnega potniškega prometa in splošnih prevoznih pogojev za avtobusne prevoznike: končno poročilo (Ljubljana: Agencija za promet).

Geurs, K.T., Ponce Dentinho, T. \& Patuelli, R. (2016) Accessibility, equity and efficiency, In: Geurs, K. T., Patuelli, R. \& Ponce Dentinho, T. (eds.) Accessibility, Equity and 
B. Korže \& I. Tucak: Justification of the Citizens' Right of Access to Public Passenger Transport Services by the Human Rights to Mobility and Equality

Before the Law

Efficiency: Challenges for Transport and Public Services (Cheltenham, UK, Northampton, MA, USA: Edward Elgar Pub), pp. 3-8.

Geurs, K.T., Van Wee, B. \& Rietveld, P. (2006) Accessibility appraisal of integrated landuse transport strategies: methodology and case study for the Netherlands Randstad area, Environment and Planning B: Planning and Design, 33(5), pp. $639-660$.

Government of the Republic of Croatia (2018a, April) Prijedlog Zakona o prijevozu $u$ cestovnom prometu, $s$ konačnim prijedlogom Zakona, Zagreb, available at: https://sabor.hr/sites/default/files/uploads/sabor/2019-01-18/081406/PZE_327.pdf (September 10, 2019).

Government of the Republic of Croatia (2018b, August 23) Vlada dodatno rasterećuje roditelje povećanjem sredstava za sufinanciranje troškova javnog prijevoza srednjoškolcima, available at: https://vlada.gov.hr/vijesti/vlada-dodatno-rasterecujeroditelje-povecanjem-sredstava-za-sufinanciranje-troskova-javnog-prijevozasrednjoskolcima/24311 (November 1, 2019).

Government of the Republic of Croatia (2017, April) National Strategy for Equalization of Opportunities for Persons with Disabilities 2017 - 2020, Official Gazette RC, No. 42/17, available at: https://mdomsp.gov.hr/UserDocsImages/Vijesti2018/National\%20Strategy\%20for\%20 Equalization $\% 20$ of $\% 20$ Opportunities\%20for\%20Persons\%20with\%20Disabilities\%20 2017\%20-\%202020.pdf (September 23, 2019).

Hananel, R. \& Joseph Berechman, J. (2016) Justice and transportation decision-making: The capabilities approach, Transport Policy, 49, pp. 78-85, https://doi.org/10.1016/j.tranpol.2016.04.005.

Igličar, A. (2000) Pravo in družba (Ljubljana: Cankarjeva založba).

Kemeter, D. (2018) Obveze jedinica lokalne samouprave prema Zakonu o prijevozu u cestovnom prometu - nove obveze komunalnom/prometnom redarstvu, Informator, 6527, 18 June 2018, available at: https://informator.hr/clanci/obveze-jedinica-lokalnesamouprave-prema-zakonu-o-dlpgc (September 15, 2019).

Korže, B. (2012) Sistemske podlage za opredelitev obsega javnih dobrin v tržno socialni državi, Proceedings of the 19th Days of Slovene Public Administration, September 2021, 2012, Ljubljana.

Korže, B. (2014) Visokošolsko izobraževanje kot mešana javno-zasebna dobrina, Javna uprava, 50(3-4), pp. 5-26.

Korže, B. (2015a) Regulatory reform of the public passenger transport system according to the European Union regulations, Zbornik Pravnog fakulteta u Zagrebu, 65(2), pp. 263280.

Korže, B. (2015b) The Right of Displaced Inhabitants in Dispersed Settlements to Special Regulation of Accessibility to Public Passenger Road Transport Services, Podjetje in delo, 41(8), pp. 1623-1636.

Korže, B. (2019) The Right of Small and Medium-Sized Enterprises to Positive Discrimination in Free Market Competition, Danube: Law, Economics and Social Issues Review, 10 (4), p. 321-346, https://doi.org/10.2478/danb-2019-0017.

Kranjc, J. (2002) Načelo enakosti: meje in možnosti, Javna uprava, 38(3), pp. 313-337.

Kušej, G., Pavčnik, M., Perenič, A. (1989) Uvod v pravoznanstvo (Ljubljana, ČZ Uradni list RS).

Lampe, R. (2010) Pravo človekovih pravic (Ljubljana: Uradni list).

Mahnič, P. (2002) Enakost in enakopravnost, Javna uprava, 38(3), pp. 357-372. 
B. Korže \& I. Tucak: Justification of the Citizens' Right of Access to Public Passenger Transport Services by the Human Rights to Mobility and Equality Before the Law

Martens, K. (2017) Transport justice: designing fair transportation systems (New York/London: Routledge).

Ministry of Infrastructure (2019) Odgovori na vprašalnik za preverjanje pravne ureditve $v$ praksi (Ljubljana: Ministry of Infrastructure).

Ministry of Regional Development and EU Funds (n. d.) Poticanje otočnog javnog cestovnog prijevoza, available at: https://razvoj.gov.hr/o-ministarstvu/djelokrug1939/otoci/poticanje-otocnog-javnog-cestovnog-prijevoza/144 (September 15, 2019).

Mudrić, M. (2018) Novi Zakon o prijevozu u cestovnom prometu i novi sustav uređenja autotaksi djelatnosti, Informator, 6540, 17 September 2018. available at: https://informator.hr/clanci/novi-zakon-o-prijevozu-u-cestovnom-prometu-i-novidmkzs (October 12, 2019).

Mužina, A. (1999) Aktualna vprašanja določitve in izvajanja lokalnih javnih služb, 5. dnevi javnega prava, 7-9 June 1999, Portorož.

Ombudsperson for Persons with Disabilities (2018) Izvješće o radu Pravobranitelja za osobe s invaliditetom 2018, available at:

http://posi.hr/wp-content/uploads/2019/04/Izvje\%C5\%A1\%C4\%87e-o-raduPravobranitelja-za-osobe-s-invaliditetom-za-2018.-godinu-1.pdf (October 10, 2019).

Pauer-Studer, H. (2000) Autonom leben: Reflexionen über Freiheit and Gleichheit (Frankfurt am Main: Suhrkamp Verlag).

Pavčnik, M. (1991) Argumentacija v pravu (Ljubljana: Cankarjeva založba).

Pereira, R., Schwanen, T. \& Banister, D. (2017) Distributive justice and equity in transportation, Transport Reviews, 37(2), pp. 170-191.

Pišek, T. (2010) Pozitivna diskriminacija (Maribor: Faculty of Law in Maribor).

Repas, M. (2010) Konkurenčno pravo v teoriji in praksi (Ljubljana: Uradni list RS).

Schmid, T. (2008) Enakost in pravičnost: med seboj povezana pojma? Socialno delo 47(1/2), pp. 65-85.

Senf, B. (2004) Die blinden Flecken der Ökonomie (München: Gaucke Verlag).

Social Work Study Centre of the Faculty of Law of Zagreb (2009, December) Socijalni položaj osoba s invaliditetom u Republici Hrvatskoj, Zagreb, available at:

https://mdomsp.gov.hr/UserDocsImages/zgrbac/Socijalnipolozaj_osoba_s_invaliditetom_u_Republici_Hrvatskoj.pdf (October 13, 2019).

Solomon, J., Titheridge, H. (2009) Setting accessibility standard for social inclusion: some obstacles, Proceedings of the 41st Universities Transport Studies Group (UTSG) Annual Conference, 5-7 Jan 2009, London.

Šadl, U. (2002) Izhodišča načela enakosti, Javna uprava, 38(2), pp. 395-410.

Šturm, L. (ed.) (2002) Komentar Ustave Republike Slovenije (Ljubljana: Fakulteta za podiplomske državne in evropske študije).

Šturm, L. (ed.) (2011) Komentar Ustave Republike Slovenije: dopolnitev - A (Kranj: Fakulteta za državne in evropske študije.

Van Wee, B. \& Geurs, K. T. (2011) Discussing equity and social exclusion in accessibility evaluations, European Journal of Transport and Infrastructure Research, 11(4), pp. 350367.

Winston, M. E. (1989) The Philosophy of Human Rights (Belmont: Wadsworth Publishing). 